\title{
Asking and Giving Response Strategy to Improve the Elementary School Sixth Graders' English Speaking Ability
}

\author{
Faridah Eka Fatmala \\ Master in Linguistics, Airlangga University, Indonesia \\ faridaheka8@gmail.com
}

\section{Abstract}

The main problem in learning English is the lack of confidence in speaking ability, which hinders one's mastery of English. This study aims to reveal the efficacy of employing asking and giving response strategy using English songs in improving the speaking ability of sixth graders' students. This research was conducted using the online classroom action research method with Google Meet as the medium, held in two cycles with two meetings in each cycle. The result of this examination indicates that the strategy of asking and giving response using English songs can improve the English-speaking ability of sixth graders' students.
Keywords

asking and giving response; speaking ability, English

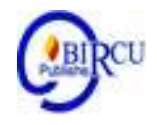

\section{Introduction}

Brown (2008) stated that English is a second language learned for a specific purpose. It is included in local subject in elementary schools. This is in accordance with Permendiknas RI No. 23 of 2006. Proven by Brown (2008) as well, he claimed that English is an international language that serves as the language of instruction in education for children studying in schools starting from the primary, secondary, and tertiary levels. The introduction of English from an early age preceded by a pedagogical concept emphasizing that the earlier a child is introduced to the target language, the better and faster he is in acquiring and mastering the language (Harmer, 1983).

English is an international-standard subject that has been curated from elementary school, middle school, to high school. Learning English refers to four learning components, namely listening, speaking, reading, and writing. In the 2013 curriculum in Indonesian education, English is not a course given explicitly in schools, but is a course included in local subject. One of the objectives of learning English is to achieve students' competence in communicating well in that language. The competence in speaking English includes three components: vocabulary, grammar, and pronunciation. Students are required to be able to express opinions and argue in English.

English language materials can be evaluated as they stand, without their roles in the classroom. However, this sort of evaluation does not help very much as it gives us no piece of information as to how the material works in the classroom (Breen, 1989). His ideas pave the ground for an evaluation of different aspects of the materials in process to get information about the ways in which students and teachers react to them. (Ali, 2019)

Educators, in implementing the learning process, employ several strategies so that students can follow the teaching and learning process effectively. In addition to that, it is also so that students can achieve certain learning objectives. Regarding to that, the use of instructional media can foster students' interest in learning in the classroom. Learning English will be captivating if the learning process is entertaining and in line with students' interests. A fun learning process will take roles on students' learning outcomes in the 
classroom. Students' English competency can be seen from their English learning achievements. Students' learning outcomes refers to the form of learning outputs which include several aspects, namely cognitive, psychomotor, and affective. Learning outcomes are the results of interactions in teaching and learning actions (Dimyati, 2006). In terms of learning outcomes, this study analyzes the learning outcomes of elementary school sixth graders in English language classroom. Students' English speaking ability is emphasized in the process of language learning. In the implementation of learning English, some students still have difficulties in learning the language. The difficulties of learning English are due to the large number of vocabularies, types of words, grammar, and tenses in English. There are still many students feeling insecure when learning that target language, especially on pronunciation or speaking in English. The problems that the students have are in terms of vocabulary learning of a sentence and its pronunciation (Maniruzzaman, 2010). Jack C. Richard (2000), supporting Maniruzzaman's view, stated that the difficulty of students in learning foreign languages is that they have to improve their speaking skill. Among the four English skills, speaking has always become the main problem between learners.

Speaking is an important skill with an important position in social life. Therefore, this skill needs to be mastered by every individual. Speaking ability is a natural phenomena and thus one will forget the first time he acquired a language until he is able to speak in that language (Thornbury, 2006). In terms of education, students are expected to be able to speak during the teaching and learning process. Students must also be able to convey, argue, as well as influence their peers with their views. In communication, good speaking skills are needed. The activity of speaking English as a foreign language can be taught as early as possible so that one's language development grows richer. Children's critical period is very good with flexibility on their brain development (Sari, 2019).

Teaching English in a formal situation can also experience difficulties, especially the use of foreign languages that are different from one's mother tongue in terms of phonology, vocabulary, writing, and grammar (Trisnadewi, 2018). Low speaking ability results in children becoming less confident in expressing their opinions. Elementary schools that teach children to use English from an early age must employ any methods so that students can understand what they learn with ease. MI Muslimat NU Pucang is a private elementary school, also known as Madrasah Ibtidaiyah, in Sidoarjo which uses the Cambridge curriculum in the teaching and learning process. The curriculum requires students and educators to use English in their daily teaching and learning processes. Referring to that, educators are also responsible for providing suitable approaches and teachings on vocabulary for students.

Based on the previous explanation, cooperation between educators and students in the teaching and learning process of English is needed. It is important to have educators who can create a pleasant learning atmosphere and make their students motivated. According to Arsyad (2011), with such educators the teaching and learning process will be full of enthusiasm so that the expected objectives are achieved. If necessary, educators might add any audio-visual media to support their teachings.

Learning media are the major factor in the success of the teaching and learning process. Media which are displayed properly will make students motivated in the teaching and learning process. Learning media in the teaching and learning process can increase students' interest in learning and motivate them during their activities in the classroom. To foster students' attention in teaching and learning activities, supporting tools, whether in the form of visuals or other objects, which are suitable for learning are needed so that students can easily understand the lessons (Shin, 2006). 
Song is a part of human's language-related experience (Schoepp, 2001). There are six advantages that Griffe highlighted in using songs in the classroom. The first is Classroom Atmosphere, which is a song that can be used to create a fun atmosphere in the classroom. The second is Language Input, which is a song that provides exposure to rhythm in a language. The third is Cultural Input, where songs can provide knowledge about culture. The fourth is Text, namely the song text that can be used as learning material such as short stories, novels, and poetry. The fifth is Supplement, which is a song as a complement to the text. The sixth is Teaching and Student Interest, namely song used to teach conversation, grammar, vocabulary, pronunciation, pattern training, as well as used as a memory enhancer (Griffe, 1992).

The effectiveness of using song as the medium of learning English in improving students' speaking skill is very good. Song-based media can help the process of transferring material from educators to students (Ratminingsi, 2016). Besides, the use of media in learning English makes students highly motivated in learning. Educators can use a strategy to deal with certain difficulties so that students can achieve learning goals without obstacles (Hamsia, 2017).

This study will reveal the strategy chosen by the researcher to show whether the asking and giving response strategy can improve the English speaking ability of the sixth graders in elementary school by applying a cognitivism approach model consisting of four stages in the research. The four stages are planning, implementing, observing, and reflecting. From this research, it will be known the effectiveness of the asking and giving response strategy on the mastery of English speaking ability in elementary school students so that students do not find it difficult to express their opinions using English both inside and outside the learning process at school.

\section{Research Methods}

This research was conducted at MI Muslimat NU Sidoarjo with the research subjects of grade VI students as many as 20 students in one class. This is due to the COVID-19 pandemic which requires the number of students in one class to be limited to a maximum of 20 students. The school was chosen as the research location because MI Muslimat NU Pucang Sidoarjo is a private school that uses the Cambridge curriculum in its learning process so that students are required to be active in using English both inside and outside the learning process.

The collected data are in the form of an assessment score on students' English speaking ability. The average score obtained will be used to determine students' ability in speaking in the targeted language, that is English. The students' scores were analyzed using the speaking ability assessment instrument by Jack C. Richard and Willy A. Renandya (2000). The instrument has been validated by experts. Student assessments according to Richard and Willy are shown as follows: 


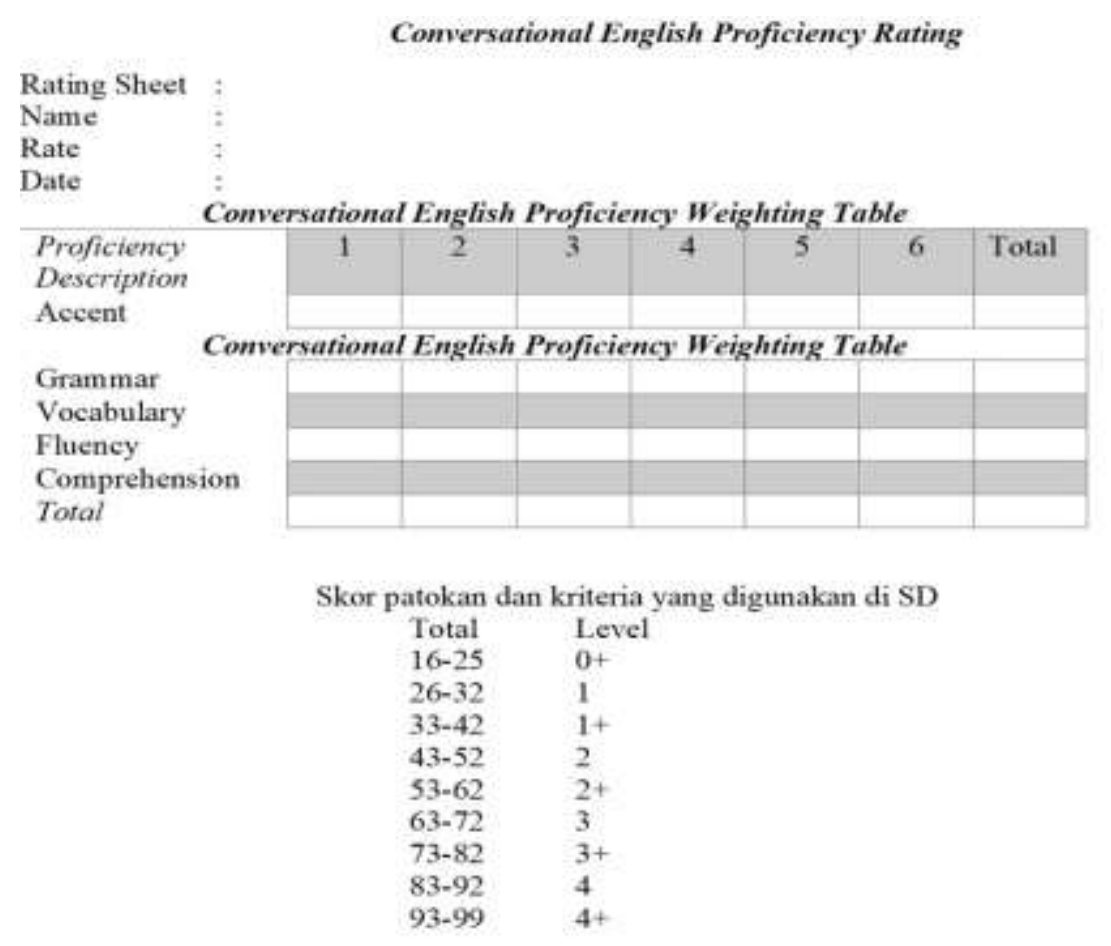

Figure 1. Speaking Ability Assessment Table

This study uses Classroom Action Research method using cognitivism approach involving four stages, namely planning, implementing, observing, and reflecting. This research is divided into two cycles, namely Cycle I and Cycle II.

The data collection process is carried out online because of the impact of the COVID19 pandemic, resulting in learning in schools through distance learning by providing material on English speaking skills followed by initial drills as a treatment. The data are collected by playing the students an English song and then students respond to the song in their language. This is done in increments of two cycles over two weeks. Each cycle in this study takes place twice to obtain data in the form of scores used as benchmarks for improving English speaking skills of the sixth graders in elementary school.

The students' average score will be analyzed quantitatively to see how motivated students are in learning speaking skills using English through English songs. The results of the analysis will be described in a qualitative descriptive way to determine the effectiveness of responding to English songs in improving the English speaking ability of elementary school students. The data analysis approach uses a cognitivism approach by describing the speaking ability assessment instrument by Richard and Renandya (2000). 


\section{Result and Discussion}

\subsection{Cycle I}

\section{a. Meeting 1}

The 1st meeting in the first week, namely on November 10, 2020, was carried out based on the planning that had been made in which there were three activities in it. The first activity was an introduction, namely the teacher opened the class by greeting the students and praying together, then continued by giving motivation and apperception. The second activity was a core activity, in which the teacher provided a short material about listening skill, then students were expected to be able to answer any questions based on the audio they had heard. The third activity was a closing activity, in which the teacher provided an evaluation on the learning that had been carried out. The evaluation was in the form of a paper test. In this closing activity, the teacher provided an evaluation of the results of learning listening skill by giving students several songs, then students were asked to respond to songs played by the teacher. After that, the teacher gave a score on the students' ability.

The class action in the learning process in order to improve the students' English speaking ability was done by having the students responding to English songs. The teacher provided the students English children's songs that were easy to be understood by elementary school students. The song at the first meeting was a song entitled Sharing Song by Cocomelon Nursery Rhymes \& Kids Songs on YouTube. After listening to the song, the teacher instructed the students to respond to it. Students might give opinions or ask questions about the song to their teacher or peers. During this activity, the researcher recorded the students' responses to the played song while the teacher gave a score to each student as a daily evaluation score in learning.

The researcher's action in the first cycle showed the score on students' speaking ability based on the asking and giving response strategy to the English song as follows:

Students' initial scores in the first meeting evaluation in Cycle I:

Table 1. Students' scores in the first meeting in cycle I

\begin{tabular}{|c|c|}
\hline Students' Number & Score \\
\hline 1. & 33,33 \\
\hline 2. & 66,66 \\
\hline 3. & 83,33 \\
\hline 4. & 59,33 \\
\hline 5. & 61 \\
\hline 6. & 86 \\
\hline 7. & 76 \\
\hline 8. & 73,66 \\
\hline 9. & 92,33 \\
\hline 10. & 55,33 \\
\hline 11. & 52 \\
\hline 12. & 91,33 \\
\hline 13. & 60,33 \\
\hline 14. & 49 \\
\hline 15. & 40,66 \\
\hline 16. & 69 \\
\hline 17. & 45,33 \\
\hline 18. & 50 \\
\hline
\end{tabular}




\begin{tabular}{|c|c|}
\hline 19. & 48 \\
\hline 20. & 78,66 \\
\hline Total Score & 1271,33 \\
\hline Average Score & 63,56 \\
\hline
\end{tabular}

From the table, it is shown that students' average score in the first meeting for evaluating their speaking ability through the asking and giving response method was 63.56, meaning at level 3. From the data, vocabulary was the aspect that was most difficult for students. Many students have difficulties remembering English vocabulary and grammar to communicate. Students with low scores had difficulties in vocabulary, grammar, and fluency to express their opinions in English. The complex vocabulary and grammar of English resulted in many students having struggles using English to communicate.

Students' abilities are assessed based on pronunciation, vocabulary, grammar, fluency, and understanding of the songs heard. The ability score could be increased. There was also an assessment of the activeness of students in the class with good enthusiasm in teaching and learning activities as well as being confident and brave to express their opinions that could increase their initial score.

\section{b. Meeting 2}

The second meeting in the first week of cycle 1 was held on November 12, 2020. The second meeting was held the same as in meeting 1 , which was based on the planning that had been made. The teacher still provided the students listening materials, then students were expected to be able to answer any questions based on the audio they heard. The third was the closing activity, in which the teacher provided an evaluation on the English learning that had been carried out. The evaluation still used a song. Students were asked to respond to the song played by the teacher, then the teacher gave a score on the students' ability.

In increasing students' learning achievement in this second meeting, the teacher provided several stimuli so that students were motivated to improve their speaking skills. The teacher provided additional vocabulary to students who had weaknesses in remembering vocabulary. In addition to that, the teacher reviewed the previous lesson on grammar that had been learned by students when they were in the third grade of elementary school. The grammar material was given as a stimulus so that students would be confident in expressing their opinions, even though they had not fully mastered grammar. The stimuli were conveyed to students with interesting concepts to boost their interest in learning grammar. Even though they learned by distance, Google Meet was used as the media to deliver the material. The vocabulary and grammar stimuli that had been given to students were then continued by improving students' listening ability.

The listening ability provided was the stimulus for students to develop their auditory sensors of English words as well as sentences. This was given by the teacher so that students could understand the vocabulary they heard. After this phase was completed, the teacher provided a final evaluation to the students in the form of English songs.

The teacher provided English children's songs that were easy to be understood by elementary school students. The song at the second meeting was a song entitled Wheels on The Bus by Cocomelon Nursery Rhymes \& Kids Songs on YouTube. After listening to the song, the teacher instructed the students to respond to the song by giving comments or asking any questions about the song to their teacher or peers. In this action, the researcher recorded the teacher's responses when giving a score to each student as their daily learning evaluation. 
The researcher's action in the first cycle showed the students' score on their speaking ability based on the asking and giving response strategy to the English song, which were as follows:

Students' second scores in the second meeting evaluation in Cycle I:

Table 2. Students' scores in the second meeting in cycle I

\begin{tabular}{|c|c|}
\hline Students' Number & Score \\
\hline 1. & 38,25 \\
\hline 2. & 64,75 \\
\hline 3. & 84,25 \\
\hline 4. & 56 \\
\hline 5. & 62,75 \\
\hline 6. & 85,25 \\
\hline 7. & 77,5 \\
\hline 8. & 75,5 \\
\hline 9. & 89,75 \\
\hline 10. & 59,25 \\
\hline 11. & 50,75 \\
\hline 12. & 91,75 \\
\hline 13. & 60,5 \\
\hline 14. & 54,5 \\
\hline 15. & 42,25 \\
\hline 16. & 64 \\
\hline 17. & 45,75 \\
\hline 18. & 50,25 \\
\hline 19. & 53,75 \\
\hline 20. & 80 \\
\hline Total Score & 1286,75 \\
\hline Average Score & 64,33 \\
\hline & \\
\hline
\end{tabular}

From this table, it is shown that the students' average score in the second meeting for evaluating their speaking ability through the asking and giving response strategy was 64.33. There was an increase in the average score from the first meeting, but their level remained the same, namely at level 3 as in the previous meeting.

The increase in the score of each student at the second meeting in the first cycle still showed a low increase compared to the first meeting. At the first meeting, the problem faced by students was about vocabulary or lack of vocabulary by students. In this second meeting, students experienced an increase in their score by $65 \%$. The remaining $35 \%$ decreased from their initial score. This improvement is quite good because students often find it difficult to maintain their scores. From this initial increase, students' average score was still the same as in the previous meeting, but has increased quite well.

\subsection{Cycle II}

a. Meeting 1

In the first meeting of the second cycle in the second week, namely on November 17 , 2020, the same planning presentation was carried out again as in the first cycle by conducting an evaluation in the closing activity as an additional student insight on speaking skill. In this 
second cycle, the teacher provided stimuli for students to increase their understanding on listening skill by providing them audios so that they were more accustomed to listening to spoken English.

In the first meeting in cycle II, the teacher improved the learning outcomes by providing some stimulus so that students were motivated to sharpen their speaking skill. In this meeting, the teacher provided additional material for students who had weaknesses in grammar. This was because in the previous meeting students were still constrained by grammar. The teacher reviewed the lesson about grammar that had been learned by students previously. The provision of grammar material was used as a stimulus so that students were able and confident in conveying their opinions in English. The stimulus was given to students with interesting concepts so that students were interested in learning. The stimulus which was in the form of grammar material was carried out with sufficient time so that students gained quality grammar material. After the students received an additional grammar material, the teacher then conducted an evaluation in the form of audios.

At the end of the meeting, the teacher provided an evaluation of learning outcomes for students by giving them a song. After that, as in previous meetings, students responded to the songs they had heard. The audio, which was an English song given by the teacher in this meeting, entitled The Ant and The Grasshopper by Cocomelon Nursery Rhymes \& Kids Songs on YouTube. At the end of the second cycle, students had begun to feel comfortable discussing through Google Meet by responding actively during the teaching and learning process. Many students have started to be brave in expressing their opinions. The increase in speaking skills can be seen from the results of the following students' scores:

Students' initial scores in the first meeting evaluation in Cycle II:

Table 3. Students' scores in the first meeting in cycle II

\begin{tabular}{|c|c|}
\hline Students' Number & Score \\
\hline 1. & 48,75 \\
\hline 2. & 69 \\
\hline 3. & 79,5 \\
\hline 4. & 88,75 \\
\hline 5. & 48,5 \\
\hline 6. & 97,75 \\
\hline 7. & 80,5 \\
\hline 8. & 80,5 \\
\hline 9. & 79,5 \\
\hline 10. & 57,25 \\
\hline 11. & 62 \\
\hline 12. & 97,75 \\
\hline 13. & 81 \\
\hline 14. & 57 \\
\hline 15. & 69,25 \\
\hline 16. & 87,25 \\
\hline 17. & 67,5 \\
\hline 18. & 81 \\
\hline 19. & 76 \\
\hline 20. & 79,75 \\
\hline Total Score & 1488,5 \\
\hline Average Score & 74,42 \\
\hline & \\
\hline & \\
\hline
\end{tabular}


The increase in the score of each student in the first meeting in cycle II showed a fairly good increase compared to the second meeting of cycle I. In this first meeting, the problems faced by students were not only vocabulary, but also the level of self-confidence of students who were still low. In the first meeting in cycle II, students experienced an increase in their score by $75 \%$. The remaining $25 \%$ has decreased compared to the previous score. This increase was quite high compared to the previous meeting. Providing an effective stimulus could help students improve their speaking skills. In this cycle, students had started to be active in expressing opinions. The asking and giving response strategy was used by the teacher to improve students' English speaking skill in responding to English songs. From the students' speech, there were still some of them who experienced a lack of confidence in expressing their thoughts in English.

From this table, it is known that the students' average score in the second cycle in the first meeting for the evaluation of speaking ability through the asking and giving response strategy was 74.42. This means that there was an increase in students' average score from the first cycle, meaning was at level 3+. The increase in students' average score indicates that the asking and giving response strategy is able to improve the English speaking ability of elementary school students.

\section{b. Meeting 2}

In the second meeting of the second cycle in the second week, namely on November 19, 2020, the same planning presentation was carried out as in the previous cycle by conducting an evaluation in the closing activity as an addition to students' insights on speaking skill. In this last cycle, the teacher provided additional stimulus to students to increase their knowledge of their listening ability so that students understood better and the learning targets for two weeks on listening and speaking skills could be achieved.

In the second meeting in cycle II, the teacher continued to improve the learning outcomes while still providing some stimulus so that students were motivated to improve their speaking skills. At this meeting, the teacher provided additional material for students who had weaknesses in terms of self-confidence because it was found in the previous meeting that students were still constrained by their lack of self-confidence to convey opinions in front of others, even though through distance learning. The teacher did not only review the material about grammar that has been studied previously by the students, but also motivated the students. This motivation used as a stimulus for students so that they were able and confident to express their opinions. The stimulus was still conveyed to students with interesting concepts so that students became attentive. The stimulus that was in the form of motivation on self-confidence was carried out for a long time, considering that selfconfidence was an important factor to foster students' interest in speaking.

Students who experienced low self-confidence were given a more serious stimulus in order to form high self-confidence. Motivation was given in a more complex way because it was the last meeting and used as the final evaluation. After students received motivation on self-confidence, the teacher then conducted an evaluation in the form of listening to audios to train students' listening skill. Not only that listening to English audios increased students' sensitivity to their hearing, but it also improved their speaking ability by listening to audiobased media.

At the end of the meeting, just like the previous meeting, the teacher gave the students an evaluation of learning outcomes by giving them a song. Students were were expected to be better at responding to the song they heard compared to the previous meetings. The audio given by the teacher in this meeting was an English song entitled Lost Hamster by Cocomelon Nursery Rhymes \& Kids Songs on YouTube. 
At the end of the second meeting in cycle II, students were getting used to responding to English songs played by the teacher. Students had a discussion through Google Meet by giving a lot of responses in the teaching and learning process. They were more confident in expressing their opinions in English. The increase in students' speaking skill could be seen from the students' scores result provided as follows:

Students' initial scores in the second meeting evaluation in Cycle II:

Table 4. Students' scores in the second meeting in cycle II

\begin{tabular}{|c|c|}
\hline Students' Number & Score \\
\hline 1. & 63,33 \\
\hline 2. & 89 \\
\hline 3. & 93,66 \\
\hline 4. & 92 \\
\hline 5. & 77,66 \\
\hline 6. & 94 \\
\hline 7. & 91 \\
\hline 8. & 93,66 \\
\hline 9. & 94 \\
\hline 10. & 76 \\
\hline 11. & 69,66 \\
\hline 12. & 92,33 \\
\hline 13. & 84,66 \\
\hline 14. & 79,33 \\
\hline 15. & 77,66 \\
\hline 16. & 94,33 \\
\hline 17. & 87,33 \\
\hline 18. & 82,66 \\
\hline 19. & 96 \\
\hline 20. & 84 \\
\hline Total Score & 1712,33 \\
\hline Average Score & 85,61 \\
\hline & \\
\hline
\end{tabular}

The increase in the score of each student in the first meeting in cycle II has shown a fairly good increase compared to the second meeting in cycle I. In this second meeting, the problems faced by students begun to be resolved quite well due to the stimulus given by the teacher before the final test. In the second meeting in cycle II, students experienced an increase in their score by $90 \%$. The remaining $20 \%$ decreased from the previous score. This increase is very good compared to the previous meeting. In short, providing an effective stimulus can help students improve their speaking skill. In this cycle, students have started to be active in giving their opinions.

The asking and giving response strategy was used by the teacher to improve students' English speaking skill in responding to English songs. From the students' speech in the second meeting of the second cycle, it can be seen that students have started well in mastering vocabulary. Besides, their mastery of English grammar improved from the beginning of the meeting to the end of this meeting.

From this table, it can be seen that the students' average score in the second cycle of the second meeting for the evaluation of speaking ability through the asking and giving response method was 85.61, meaning there was an increase in the average of the first and second 
meeting in cycle I and the first meeting in cycle II. In this last meeting, the mean score of students had entered level 4.

Based on the scores table of students in each meeting, it can be concluded that there was an increase in this last meeting compared to the previous one. In the first meeting in cycle I, the average score was 63.56 , which was at level 3 . In the second meeting in cycle I, the average score increased to 64.33 and was still at level 3, but there was an increase in the number of scores and the average score. In the first meeting in cycle II, using the same method, the mean score was 74.42 , which was at level $3+$. In the second meeting in cycle II, the average score increased quite high, namely to 85.61 and was at level 4 .

This shows that the asking and giving response strategy can help improve students' English speaking ability in elementary school level. The improvement of students' English speaking skills from the first meeting to the last meeting is depicted in a bar chart provided as follows:

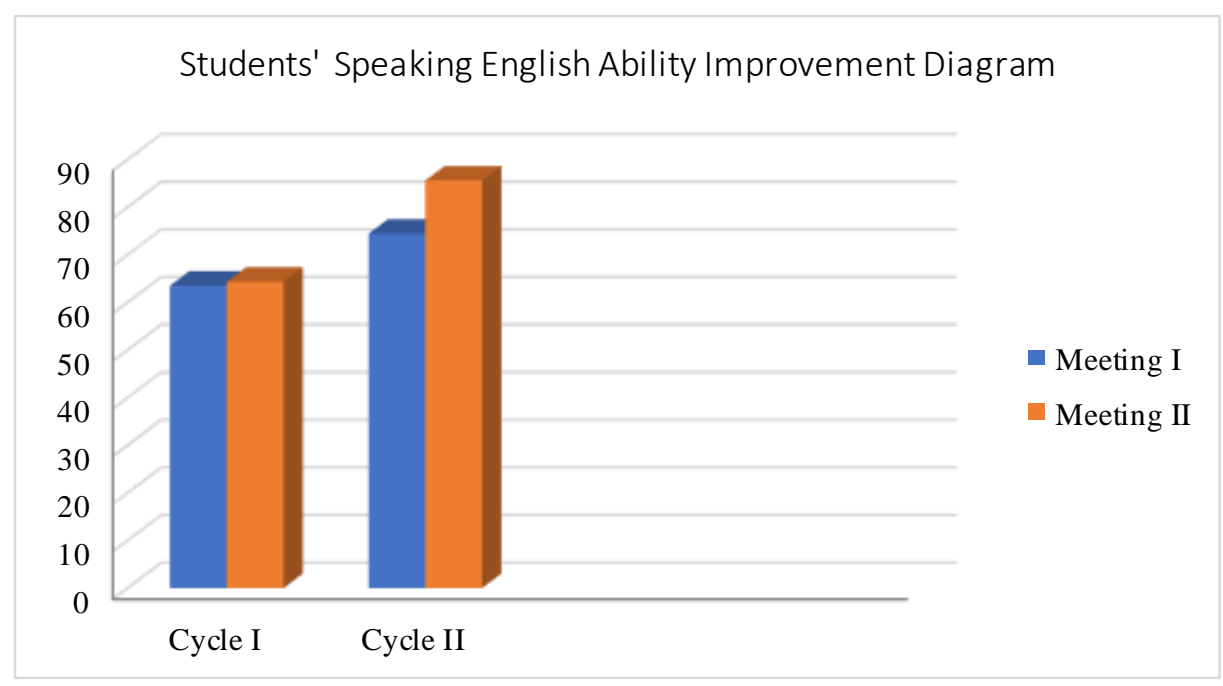

Figure 2. Students' speaking English ability improvement

\section{Conclusion}

There are several aspects of learning English. One of them is speaking ability which is quite important since it serves as a communication tool. Each student needs to be able to master this skill so that he can speak English skillfully. In this study, the success in speaking English was very limited because students' interest in speaking in the target language was very low. This was indicated by the lack of confidence in expressing opinions in English. Apparently, the use of asking and giving response strategy using English songs can help improve the English speaking ability of elementary school students. This is because audio media provide a pleasant atmosphere in the classroom, helping students sharpen their listening ability.

Based on data, in the first meeting in cycle I, the average score of grade 6 ICP 2 students was 63.56, meaning at level 3. In the second meeting in cycle I, their average score increased to 64.33 and was still at level 3. However, there was an increase in the number of scores as well as the average score. In the first meeting in cycle II, using the same strategy, the average score obtained was 74.42, meaning at level $3+$. In the second meeting in cycle II, the average score increased quite high, namely to 85.61 and thus students were at level 4 . In conclusion, the strategy of asking and givng response using English songs can be used as an effective means to help elementary school students improve their English speaking ability. 


\section{References}

Ali, W. (2019). Cooperative Learning (CL) in Promoting Oral Group Lessons. Budapest

International Research and Critics Institute-Journal (BIRCI-Journal). P. 299-306.

Arsyad, A. (2011). Media Pembelajaran. Jakarta: PT Raja Grafindo Persada.

Brewster, J., Ellis, G., \& Girard, D. (1992). The Primary English Teacher's Guide. Penguin English.

Brown, H. D. (2001). Teaching by Principles: An Interactive Approach to Language Pedagogy. New York: Person Education. pp. 271-274. . (2008). Prinsip Pembelajaran dan Pengajaran Bahasa, edisi kelima, Kedutaan Besar Amerika Serikat di Jakarta.

Campbell, D., Shadish, W. R., \& Cook, T. D. (2001). Experimental Designs for Generalixed Causal Inference. Boston: Houghton Miffin Company.

Dimyati, M. (2006). Belajar dan Pembelajaran. Jakarta: Rineka Cipta.

Flavell, J. H. (1979). Metacognitive aspects of problem solving. In L. B. Resnick (Ed), The nature of intelligence. Hilldale, NJ: Elbaum.

(1979). Teori of Learning in Educational Psycholog: A new area of cognitive development inquiry. American Psychologist. 34.906-911.

Griffe, D. T. (1992). Songs in Action. Prentice Hall.

Hamsia, Waode. (2017). Strategi Metakognitif untuk Keterampilan Berbicara Bahasa Inggris. Jurnal Pendidikan dan Pembelajaran Sekolah Dasar, 1(2b), 153-159.

Harmer, J. (1983). The Practice of English Language Teaching. ERIC.

Maniruzzaman, M. (2010). Students' Attitude Towards Their Learning Situation and Their Achievement in EFL. United States: Dorrance Publishing Company.

Paul, D., \& Chan, M. (2010). Teaching English to Children in Asia. Pearson: Longman Asia.

Ratminingsih, N.M. (2016). Efektivitas Media Audio Pembelajaran Bahasa Inggris Berbasis Lagu Kreasi di Kelas Lima Sekolah Dasar. Jurnal Pendidikan Indonesia, 5(1), 27-38.

Richard, Jack C. and Willy A. Renandya. (2002). Methodology in Language Teaching an Anthology of Current Practice. Cambridge: University Press.p.210.

Sari, L., \& Lestari, Z. (2019, February). Meningkatkan Kemampuan Berbicara Bahasa Inggris Siswa dalam Menghadapi Era Revolusi 4.0. In Prosiding Seminar Nasional Program Pascasarjana Universitas PGRI Palembang (Vol. 12, No. 01).

Schoepp, K. (2001). Reasons for Using Songs in the ESL/EFL Classroom. The Internet TESL Journal, 7(2), 1-4.

Shin, J.K. (2006). Ten Helpful Ideas for Teaching English to Young Learners. English Teaching Forum, 44(2).

Thornbury, Scott. (2006). How to Teach Speaking. UK: Pearson Education.

Trisnadewi, K., \& Lestari, E. A. P. (2018). Pengaruh Language Games Terhadap Kemampuan Berbicara Bahasa Inggris. KULTURISTIK: Jurnal Bahasa dan Budaya, 2(1), 66-78. DOI: dx.doi.org/10.22225/kulturistik.2.1.674 